\title{
Tingkat Keberhasilan Pertumbuhan Stek Lada dengan Aplikasi Naungan dan Berbagai Hormon Tumbuh Auksin
}

\author{
The Growth of Black Pepper Cutting as Effect of Shading and Auxin Growing Hormone \\ Eni Handayani $^{1 *}$, Tantri Palupi $^{1}$, Fadjar Rianto $^{1}$ \\ ${ }^{1}$ Program Studi Magister Agroteknologi, Fakultas Pertanian, Universitas Tanjungpura \\ *Email korespondensi: enigiza@gmail.com
}

Diterima: 04 Agustus 2020 / Disetujui: 02 September 2020

\begin{abstract}
One of the successes of black pepper production is influenced by the use of healthy and good quality black pepper seedlings. Black pepper nurseries are directed to produce quality black pepper seedlings with a faster seeding time. The research aims to determine the growth of pepper cuttings due to shade and auxin treatment. The study was conducted in Jerora I village, Sintang district, in August-December 2018. The study used a split-plot model research design. The main plot was shade (shade $25 \%(n 1)$ and shade $75 \%(n 2))$ and subplots in the form of auxin hormone treatment (ho as control, (h1) 1\% synthetic IAA, (h2) onion extract, and (h3) sprout extract using pepper cuttings using pepper cuttings. 3 sections and shading treatment using paranet. The administration of auxin treatment is done by immersing the tip of cuttings for 3 hours, pepper cuttings are placed in a lid to keep moisture in. The results showed that the percentage of cutting growth at $75 \%$ shade was higher than the shade of 25\% IAA hormone use. can increase plant height at the beginning of growth, number of leaves and root dry weight. The origin of IAA used from natural ingredients is better than the synthetic type as evidenced by the results of the application of the sprouts extract, namely producing a root dry weight of $0.42 \mathrm{~g}$, and a root shoot ratio of $0.61 \%$. Increased growth due to IAA growth is better if placed in a darker shade that is $75 \%$ paranet shade.
\end{abstract}

Keywords: cuttings growth, shallot extract, sprout extract, synthetic IAA.

\section{ABSTRAK}

Keberhasilan produksi lada salah satunya dipengaruhi oleh penggunaan bibit lada yang sehat dan berkualitas baik. Pembibitan lada diarahkan untuk menghasilkan bibit lada yang berkualitas dengan waktu pembibitan yang lebih cepat. Penelitian bertujuan untuk menentukan pertumbuhan stek lada akibat perlakuan naungan dan auksin. Penelitian dilakukan di desa Jerora I kabupaten Sintang, pada bulan Agustus-Desember 2018. Penelitian menggunakan rancangan penelitian model petak terbagi. Petak utama adalah naungan (n1 naungan 25\% dan $n 2$ naungan $75 \%$ ) dan anak petakberupa perlakuan hormone auksin (ho kontrol, h1 IAA sintetik 1\%, h2 ekstrak bawang merah, dan h3 ekstrak kecambah. Stek lada menggunakan 3 ruas dan perlakuan naungan menggunakan paranet. Pemberian perlakuan auksin dilakukan dengan perendaman ujung stek selam 3 jam. Stek lada ditempatkan dalam sungkup untuk menjaga kelembaban. Hasil penelitian menunjukkan bahwa persentase tumbuh stek pada naungan $75 \%$ lebih tinggi dibandingkan naungan $25 \%$. Penggunaan hormon IAA dapat meningkatkan tinggi tanaman saat awal pertumbuhan, jumlah daun dan berat kering akar. Asal IAA yang digunakan dari bahan alami lebih baik dibandingkan dengan jenis sintetik dibuktikan dengan hasil dari aplikasi ekstrak kecambah yaitu menghasilkan berat kering akar 0,42 g, dan rasio pucuk akarnya 0,61\%. Peningkatan pertumbuhan stek lada akibat IAA lebih baik jika ditempatkan pada naungan yang lebih gelap yaitu naungan paranet $75 \%$.

Kata kunci: ekstrak bawang merah, ekstrak kecambah, IAA sintetik, pertumbuhan stek.

\section{PENDAHULUAN}

Lada merupakan tanaman perkebunan yang mempunyai prospek sangat bagus dalam meningkatkan perekonomian masyarakat. Sejalan dengan meningkatnya produksi maka diharapkan akan berdampak pada peningkatan kesejahteraan petani lada. Pengelolaan dasar lada agar produktivitas tetap tinggi diantaranya pengendalian organisme pengganggu tanaman, pemupukan dan pemakaian mulsa, pengairan saat musim kering, pemangkasan dan menjaga perambatan (Nelson \& Canon, 2011)
Produksi bibit lada dengan stek merupakan salah satu cara perbanyakan tanaman yang efektif dan efisien dalam budidaya tanaman lada. Stek lebih menguntungkan karena menghasilkan populasi tanaman yang homogen dan memiliki sifat yang sama dengan induknya. Perbanyakan untuk mendapatkan bibit secara cepat dilakukan melalui kultur jaringan dengan menambahkan hormon tumbuh pada media (Hussain et al., 2011). Salah satu keberhasilan stek, terutama yang dilakukan secara konvensional adalah terbentuknya akar adventif pada stek. Upaya untuk memperbesar keberhasilan tumbuh stek dapat dilakukan dengan perangsangan 
pembentukan akar dan menjaga kelembaban media. Penggunaan hormon tumbuh dan pemberian naungan menjadi pilihan yang daat diterapkan.

Usaha untuk mendapatkan bibit lada yang berkualitas dan relatif singkat dapat dilakukan dengan penggunaan hormon pertumbuhan auksin dan juga perlakuan naungan. Penggunaan rizobakteria, Bacillus cereus dapat menginduksi pembentukan akar pada stek lada. Akibat penggunaan bakteri dapat meningkatkan pembentukan jumlah akar, panjang akar, berat basah dan kering akar dibandingkan dengan tanaman kontrol. Bakteri yang digunakan tersebut menghasilkan IAA dan juga siderofor (Aziz et al., 2015 dan Dastager et al., 2011). Penggunaan naungan pada pembibitan lada dapat dimanfaatkan untuk meningkatkan kemampuan tumbuh stek. Hal serupa juga terjadi dengan penggunaan PGPR, Serratia nemathodiphila menyebabkan peningkatan pertumbuhan, panjang akar dan jumlah akar stek lada (Dastager et al., 2011). Perlakuan naungan yang dilakukan oleh Zuet al. (2016) pada lada ternyata dapat menurunkan produksi dan kualitas buah lada. Hal ini berkaitan dengan kegiatan fotosintesis dan temperatur. Temperatur sangat penting dalam menentukan perkecambahan benih lada yang bersifat rekalsitran (Li et al., 2010), demikian juga dalam keberhasilan tumbuh pada stek. Kombinasi perlakuan naungan dan hormon auksin pada stek lada diharapkan dapat mengurangi kegagalan tumbuh.

Tujuan dari penelitian ini adalah mengkaji perlakuan naungan dan penggunaan hormone tumbuh auksin terhadap pertumbuhan stek lada. Cara ini diharapkan dapat meningkatkan penyediaan bibit berkualitas sehingga bisa mendorong produksi lada.

\section{BAHAN DAN METODE}

\section{Waktu dan Tempat}

Penelitian dilakukan di Desa Jerora I Kecamatan Sintang Kabupaten Sintang. Rancangan percobaanyang digunakan adalah petak terbagi dengan petak utama (main plot) adalah naungan yang terdiri dari 2 taraf, yaitu $n 1=$ naungan $25 \%$ dan $\mathrm{n} 2=$ naungan $75 \%$. Anak petak (sub plot) adalah hormon auksin yang terdiri dari 4 taraf, ho= kontrol, $\mathrm{h} 1=$ IAA sintetis $1 \%, \mathrm{~h} 2=$ Ekstrak bawang merah dan h3=Ekstrak kecambah. Setiap perlakuan diulangi 3 kali. Setiap unit percobaan terdiri dari 4 stek.

\section{Alat dan Bahan}

Varietas yang digunakan adalah Semungguk Emas, salah satu varietas lokal daerah Sintang.Bahan stek adalah sulur panjat, menggunakan tiga ruas. Setiap stek menyisakan satu helai daun.

\section{Persiapan Bibit}

Sebelum ditanam pada media terlebih dahulu stek direndam dalam larutan IAA sesuai perlakuan. Media pembibitan merupakan campuran antara tanah, pasir dan kompos dengan perbandingan 1:1:1 Media ini dimasukan dalam polibag ukuran $7 \times 14 \mathrm{~cm}$ dan diletakkan dalam kubung yang dilapisi paranet $25 \%$ dan $75 \%$ sesuai dengan perlakuan naungan. Selama dalam kubung kelembaban media diusahakan tetap lembab dengan cara menyiram melalui pengkabutan menggunakan sprayer.

\section{Persiapan Hormon}

Pembuatan larutan IAA baik yg sintetik dan ekstrak bawang merah dan kecambah diawali dengan uji keberadaan senawa indol. Deteksi keberadaan senyawa indol pada ekstrak bawang merah dan kecambah menggunakan pereaksi Kovac. Larutan IAA sintetik disiapkan dengan melarutkan serbuk IAA kedalam aquades yang sudah ditambahkan alkohol $96 \%$. Ekstrak bawang merah dan kecambah disiapkan dengan menghaluskan bahan tanaman tersebut dan ditambah aquades dengan perbandingan 1:1. Penambahan bahan tanaman (bawang merah atau kecambah) dilakukan jika hasil uji keberadaan auksin rendah, warna merah tidak sama dengan IAA sintetik.

\section{Variabel Pengamatan}

Pengamatan dilakukan terhadap keberhasilan tumbuh stek lada dengan menghitung persentase tumbuh stek dan kecepatan waktu munculnya tunasstek lada. Pengamatan pertumbuhan stek lada juga dilakukan dengan pengukuran tinggi tanaman, penghitungan jumlah daun pada setiap bulan dari awal pembibitan, dan pengukuran luas daun, penimbangan berat pucuk dan akar dilakukan pada akhir penelitian. Pengamatan variabel pesentase tumbuh stek dilakukan dari awal tanam sampai usia 12 MST, sedangkan variabel tinggi tanaman dan jumlah daundilakukan pada setiap minggu dimulai dari awal tanam sampai usia 16 MST. Vaiabel luas daun, berat kering pucuk dan berat kering akar dilakukan pada akhir penelitian.

\section{HASIL DAN PEMBAHASAN}

\section{Persentase StekTumbuh}

Persentase stek lada yang tumbuh dipengaruhi hanya oleh naungan pada 12 mst. Faktor pemberian hormon tumbuh auksin tidak mempengaruhi stek yang tumbuh.

Tabel 1. Rerata Persentase Stekakibat naungan pada 12 mst.

\begin{tabular}{cc}
\hline Tingkat Naungan & PersentaseStekTumbuh(\%) \\
\hline $25 \%$ & $81,6 \mathrm{~b}$ \\
$75 \%$ & $95 \mathrm{a}$ \\
\hline
\end{tabular}

Keterangan : Angka yang diikuti huruf yang berbeda pada kolom yang sama menunjukkan hasil yang berbeda nyata berdasarkan uji BNJ $\alpha=5 \%$; mst = minggu setelah tanam

Pada Tabel 1 terlihat bahwa perlakuan naungan $75 \%$ menyebabkan perentase stek yang tumbuh lebih tinggi dan berbeda dengan yang diberi perlakuan naungan $25 \%$. Hasil penelitian pemberian naungan dan air pada stek cabai jamu menunjukkan hasil bahwa semakin tinggi naungan dan air ke 
media menyebabkan pertumbuhan dan keberhasilan tumbuh stek cabai jamu juga menjadi lebih tinggi (Nurkhasanah et al., 2013). Perkecambahan biji lada ditentukan pula oleh kelembaban yang ditimbulkan akibat perlakuan naungan Kelembaban dan temperatur menjadi unsur penting terhadap perkecambahan biji lada (Li et al., 2010). Hasil pengukuran rata kelembaban udara dalam kubung yang diberi naungan $75 \%$ memiliki kelembaban mencapai $80,25 \%$ dengan temperatur $24,8^{\circ} \mathrm{C}$. Kelembaban yang tercipta lebih tinggi dibandingkan naungan $25 \%$ yang hanya mencapai $70,6 \%$ dengan temperatur mencapai $26,13^{\circ} \mathrm{C}$.

Intensitas cahaya, kelembaban dan temperatur berhubungan dengan metabolisme tanaman. Saat pembentukan bunga dan buah, pertumbuhan tunas lada memerlukan naungan. Hanya saja pada kondisi tersebut menjadi rawan untuk perkembangan penyakit (Thomas \& Rajeev, 2015). Pada penelitian ini diperoleh bahwa mengurangi intensitas cahaya dengan cara memberikan naungan menyebabkan peningkatan pada tinggi tanaman (Tabel 2).

\section{Tinggi Tanaman}

Perlakuan naungan dan penggunaan auksin berpengaruh juga terhadap tinggi tanaman. Peningkatan tinggi tanaman sampai $16 \mathrm{mst}$ lebih tinggi terjadi jika naungan menggunakan paranet $75 \%$ dibandingkan jika naungan yang menggunakan paranet $25 \%$. Auksin yang berasal dari bahan alami (bawang merah dan kecambah) lebih baik dibandingkan sintetik. Tinggi stek lada yang diberi auksin asal umbi bawang merah lebih tinggi dibandingkan perlakuan lainnya, baik pada naungan $25 \%$ ataupun $75 \%$. Kerja hormon tumbuh erat kaitannya dengan cahaya. Pengaruh auksin dan naungan terhadap tinggi tanaman hanya terjadi sampai 8 mst, tetapi setelah itu tidak terjadi pengaruh kedua faktor terhadap tinggi bibit stek lada.

Naungan cenderung untuk menghambat distribusi auksin, sehingga akan terkonsentrasi pada bagian tanaman yang kurang mendapat sinar. Pada perlakuan naungan hormon auksin dapat disebarkan ke banyak bagian tanaman sehingga tumbuh dan kecepatan tumbuh normal. Auksin akan aktif bekerja pada kondisi intensitas cahaya yang rendah atau disebut fototropik negatif, hal ini sesuai dengan hasil penelitian ini dimana stek lada yang berada pada intensitas cahaya rendah memiliki tinggi tanaman dan jumlah dau yang lebih tinggi.

Meningkatnya tinggi tanaman tidak lepas dari pengaruh aktivitas kerja hormon dalam jaringan tanaman. Distribusi auksin yang terjadi di pucuk-pucuk tanaman akan lebih baik bila intensitas radiasi matahari kurang. Jika tanaman ternaungi pemanjangan sel lebih cepat tumbuh memanjang. Gardner \& Mitchell (1991) menyatakan auksin merupakan istilah genetic substansi pertumbuhan yang khususnya merangsang perpanjangan sel di hasilkan oleh tanaman itu sendiri dalam jumlah sedikit.

\section{Luas Daun}

Luas daun stek lada tidak dipengaruhi oleh faktor naungan dan penggunaan horon. Hasil rerata luas daun akibat perlakuan naungan dan hormone dapat dilihat pada Gambar 1. Pada stek lada, naungan dan hormon auksin lebih mengarah pada pemanjangan ruas tunas dan petiol yang menjadi lebih panjang, sehingga perkembangan daun menjadi terhambat. Perlakuan hormone menyebabkan perbedaan pada tinggi tanaman stek lada, diantaranya disebabkan oleh pemanjangan tunas stek.

\section{Berat Kering Pucuk}

Pada variabel berat kering pucuk tidak dipengaruhi oleh faktor naungan dan hormon auksin. Rerata berat kering pucuk dapat dilihat pada Gambar 2. Semakin tinggi berat kering pucuk menunjukkan bahwa pertumbuhan vegetatif tanaman berjalan dengan baik. Apabila respirasi lebih besar dari fotosintesis, maka berat kering berkurang. Produksi berat kering tergantung pada penyerapan, penyinaran matahari serta pengambilan $\mathrm{CO} 2$ dan air. Faktor naungan dan hormon tidak berpengauh pada tinggi tanaman 12 dan 16 mst. Pengukuran berat yang dilakukan pada 16 mst sama hasilnya dengan tinggi tanaman. Tinggi tanaman merupakan salah satu hasil dari pertumbuhan tanaman.

\section{Jumlah daun}

Jumlah daun stek lada hanya dipengaruhi oleh faktor penggunaan jenis asal auksin. Terjadi peningkatan jumlah daun sejalan dengan waktu pengamatan dilakukan yang menandakan stek aktif tumbuh. Pada awal pengamatan, sampai 4 mst tidak terjadi perbedaan diantara perlakuan asal auksin, perbedaan terjadi mulai $8 \mathrm{mst}$.

Adanya pemberian hormon auksin pada stek lada dapat meningkatkan jumlah daun yang terbentuk. Hormon sintetik IAA kurang baik dibandingakan auksin yang berasal dari ekstrak tanaman setelah 4 minggu. Daun yang terbentuk lebih banyak pada stek yang direndamkan pada ekstrak bawang merah yang dapat mencapai 9 helai. Hormon IAA eksternal yang diberikan melalui perlakuan rizobacteria dapat meningkatkan pertumbuhan stek lada pada bagian pucuk dan akar (Dastager et al., 2011a dan b). Pemberian auksin seperti yang terdapat dalam Atonik dapat meningkatkan pertumbuhan bagian pucuk dan akar stek lada (Ulfa et al., 2017).Demikian pula diantara penggunaan beberapa jenis auksin dengan komposisi NAA $250 \mathrm{mgl}^{-1}+\mathrm{IBA}^{2} 250 \mathrm{mgl}^{-}$ ${ }^{1}$ merupakan yang terbaik dalam menginisiasi pertumbuhan pucuk dan akar, kecepatan keluar tunas stek, jumlah daun, panjang tunas (Prajapati et al., 2018).

Hormon tumbuh mampu mendorong kemunculan tunas yang lebih cepat sehingga mampu menambah banyaknya jumlah tunas baru dan jumlah daun. Jumlah daun selain dipengaruhi oleh banyaknya jumlah tunas juga dipengaruhi oleh waktu kemunculan tunas. Penggunaan hormon auksin baik yang sintesik maupun yang alami mampu mempercepat kemunculan tunas sehingga mampu menambah jumlah tunas yang baru yang kemudian akan menyebabkan bertambahnya jumlah daun.

\section{Berat kering akar}


Tabel 2. Rerata tinggi tanaman stek lada akibat perlakuan naungan dan hormon auksin.

\begin{tabular}{|c|c|c|c|c|c|}
\hline & \multirow{2}{*}{ Perlakuan } & \multicolumn{4}{|c|}{ Tinggi Tanaman $(\mathrm{cm})$} \\
\hline & & $4 \mathrm{MST}$ & $8 \mathrm{MST}$ & $12 \mathrm{MST}$ & $16 \mathrm{MST}$ \\
\hline \multirow{4}{*}{ Naungan $25 \%$} & - Kontrol & $4,1 \mathrm{c}$ & $7,3 \mathrm{c}$ & 12,4 & 13,4 \\
\hline & -IAA & $5,1 \mathrm{bc}$ & $9,2 \mathrm{bc}$ & 18,5 & 20,0 \\
\hline & - Ekstrak bawang & 6,0 a & $11,3 \mathrm{a}$ & 20,3 & 24,1 \\
\hline & -Ekstrak kecambah & $5,1 \mathrm{bc}$ & $10 \mathrm{bc}$ & 17,4 & 19,3 \\
\hline \multirow{4}{*}{ Naungan $75 \%$} & -Kontrol & $4,4 \mathrm{bc}$ & $8,6 \mathrm{bc}$ & 13,2 & 14,3 \\
\hline & - IAA & $6,0 \mathrm{~b}$ & $11,3 \mathrm{~b}$ & 18,8 & 22,6 \\
\hline & -Ekstrak bawang & $8,2 \mathrm{a}$ & 17,3 a & 25,3 & 29,3 \\
\hline & -Ekstrak kecambah & $5,6 \mathrm{bc}$ & $11,1 \mathrm{~b}$ & 17,6 & 20,0 \\
\hline
\end{tabular}

Keterangan: Angka yang diikuti huruf yang berbeda pada kolom yang sama menunjukkan berbeda nyata berdasarkan uji BNJ $\alpha=5 \%$; mst=minggu setelah tanam.

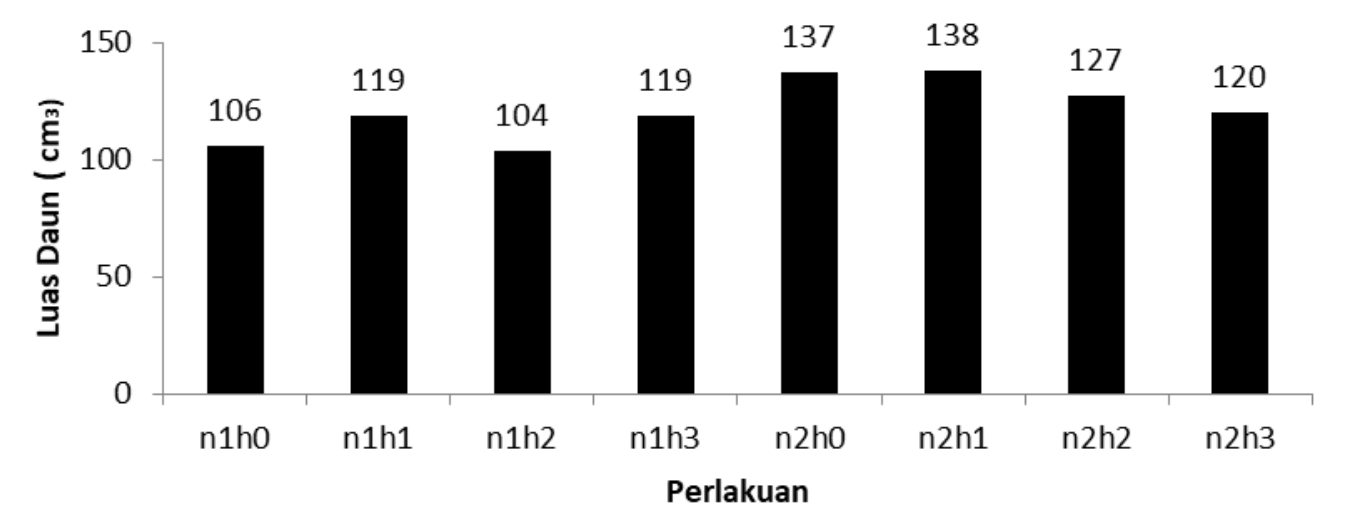

Keterangan: $\mathrm{n}=$ Naungan $(\mathrm{n} 1=25 \% ; \mathrm{n} 2=75 \%), \mathrm{h}=$ Hormon $(\mathrm{h} 0=$ kontrol, $\mathrm{h}=\mathrm{IAA}, \mathrm{h} 2=$ Ekstrak bawang, $\mathrm{h} 3=$ Ekstrak kecambah.

Gambar1. Rerata luas daun stek lada dengan aplikasi hormon dan naungan.

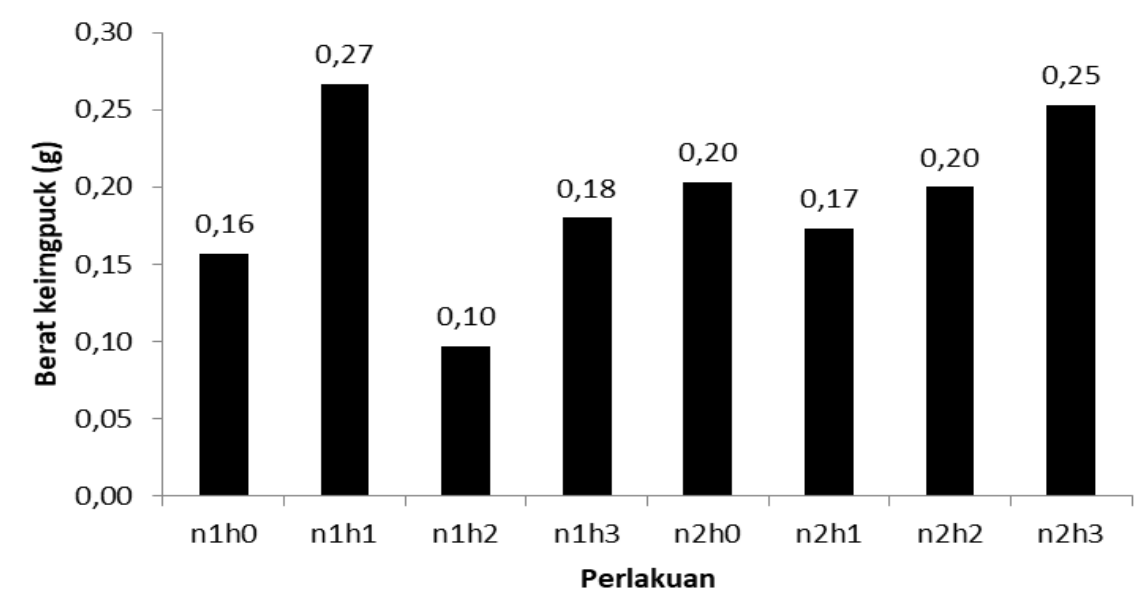

Keterangan: $\mathrm{n}=$ Naungan $(\mathrm{n} 1=25 \%$; $2=75 \%)$, h=Hormon (h0=kontrol, h1=IAA, h2=Ekstrak bawang, h3=Ekstrak kecambah.

Gambar 2. Rerata berat kering pucuk stek lada akibat perlakuan naungan dan hormon auksin. 
Tabel 3. Rerata jumlah daun stek lada akibat aplikasi berbagai jenis asal auksin

\begin{tabular}{lcccc}
\hline \multirow{2}{*}{ JenisHormon } & \multicolumn{4}{c}{ JumlahDaun( Helai ) } \\
\cline { 2 - 5 } & 4 & 8 & 12 & 16 \\
& MST & MST & MST & MST \\
\hline Kontrol & $2,6 \mathrm{~b}$ & $3,0 \mathrm{c}$ & $3,7 \mathrm{c}$ & $3,5 \mathrm{c}$ \\
IAA $(0,1 \%)$ & $3,8 \mathrm{a}$ & $4,9 \mathrm{~b}$ & $5,2 \mathrm{~b}$ & $5,2 \mathrm{~b}$ \\
EkstrakBawang & $4,3 \mathrm{a}$ & $6,9 \mathrm{a}$ & $9,0 \mathrm{a}$ & $9,0 \mathrm{a}$ \\
EkstrakKecambah & $4,0 \mathrm{a}$ & $5,0 \mathrm{a}$ & $6,3 \mathrm{a}$ & $6,0 \mathrm{~b}$ \\
\hline
\end{tabular}

Keterangan: Angka yang diikuti huruf yang berbeda pada kolom yang sama menunjukkan hasil yang berbeda nyata berdasarkan uji $\mathrm{BNJ} \alpha=5 \%$; mst=minggu setelah tanam.

Tabel 4. Rerata berat kering akar akibat penggunaan hormon auksin dan naungan

\begin{tabular}{lll}
\hline & Perlakuan & $\begin{array}{c}\text { Berat kering } \\
\text { akar(g) }\end{array}$ \\
\hline Naungan & Kontrol & $0,14 \mathrm{c}$ \\
$25 \%$ & IAA & $0,15 \mathrm{c}$ \\
& Ekstra bawang & $0,35 \mathrm{ab}$ \\
& Ekstra kecambah & $0,21 \mathrm{bc}$ \\
\hline Naungan & Kontrol & $0,25 \mathrm{~b}$ \\
& IAA & $0,17 \mathrm{c}$ \\
& Ekstra bawang & $0,34 \mathrm{ab}$ \\
& Ekstra kecambah & $0,42 \mathrm{a}$ \\
\hline
\end{tabular}

Keterangan: Angka yang diikuti huruf yang berbeda pada kolom yang sama menunjukkan berbeda nyata berdasarkan uji $\mathrm{BNJ} \alpha=5 \%$.

Pengukuran berat kering akar diharapkan menjadi reprentasi perkembangan akar dari stek. Akar yang diberi perlakukan hormon lebih berkembang pada kondisi naungan yang lebih gelap (naungan 75\%). Pada Tabel 4 terlihat pengaruh IAA sintetik menyebabkan pertumbuhan akar yang rendah, dan berbeda dengan auksin yang berasal dari bahan tanaman. Daya kerja hormon juga lebih meningkat dalam membantu perkembangan akar jika naungan yang digunakan lebih rapat.

Berat kering akar mencerminkan indikator pertumbuhan. Akar sangat menopang untuk pertumbuhan stek. Akar yang berkembang dapat menunujukkan kelancaran transport dan penyerapan hara dan air dari tanah. Hasil analisis sidik ragam berat kering akar bibit lada menunjukkan bahwa interaksi naungan dan hormone berpengaruh nyata, penggunaan naungan $75 \%$ dan penggunaan hormon auksin dengan ektrak bawang merah mempunyai berat kering akar terberat. Hal ini karena interaksi naungan dan hormon mampu meningkatkan efesiensi metabolism dan asimilasi bersih tanaman. Berat kering akar tanaman merupakan penimbunan hasil bersih asimilasi $\mathrm{CO}_{2}$ dan fotosintesis selama pertumbuhan (Gardner et al., 1991). Semakin tinggi berat kering akar tanaman maka reaksi metabolism semakin baik karena tanaman memiliki daun yang kokoh sehingga proses fotosintesis berjalan lancar. Fotosintat yang dihasilkan akan mempengaruhi berat kering akar.

\section{KESIMPULAN}

Kerja hormon IAA dalam membantu pertumbuhan stek lada lebih baik pada nanguan yang lebih rapat, terutama pada persentase stek yang tumbuh, berat akar, tinggi tanaman stek pada awal pertumbuhan, jumlah daun. Pengaruh hormon auksin (IAA) yang berasal dari bahan tumbuhan lebih baik dibandingkan IAA sintetik terhadap pertumbuhahan stek.

\section{DAFTAR PUSTAKA}

Ab Aziz, Z. F., Saud, H. M., Kundat, F. R., Jiwan, M., \& Wong, S. K. (2015). Rhizobacterium Bacillus cereus induced root formation of pepper (Piper nigrum L.) stem cutting. Research in biotech 6(2).

Dastager, S. G., Deepa, C. K., \& Pandey, A. (2011). Growth enhancement of black pepper (Piper nigrum) by a newly isolated Bacillus tequilensis NII0943. Biologia, 66(5), 801.

Dastager S.G., Deepa C.K., Pandey A (2011b). Potential plant growth-promoting activity of Serratia nematodiphila NII-0928 on black pepper (Piper nigrum L.). World Jurnal Microbiol Biotechnol 27,259-265.

Gardner \& Mitchel, (1991). Fisiologi Tanaman Budidaya. Kanisius, Yogyakarta.

Hussain, A., Naz, S., Nazir, H., \& Shinwari, Z. K. (2011). Tissue culture of black pepper (Piper nigrum L.) in Pakistan. Pak. J. Bot, 43(2),1069-1078.

Li, Z., Liu, A., Wu, H., Tan, L., Long, Y., Gou, Y., ... \& Sang, L. (2010). Influence of temperature, light and plant growth regulators on germination of black pepper (Piper nigrum L.) seeds. African Journal of Biotechnology, 9(9).

Nelson, S. C., \& Cannon-Eger, K. T. (2011). Black pepper. Farm and Forestry Production, 45(1),14.

Nurkhasanah, N., Wicaksono, K. P., \& Widaryanto, E. (2013). Studi pemberian air dan tingkat naungan terhadap pertumbuhan bibit tanaman cabe jamu (Piper retrofractum Vahl.). Jurnal Produksi Tanaman, 1(4), 325-332.

Prajapati N., Padhiar B. V., Patel P.U., \& Patel P. (2018). Effect of plant growth regulators on rooting of cutting in black pepper (Piper nigrum L.) cv. Panniyar-1 under protected condition. Trends Biosciences 11(11): 2133-2136

Salsbury \& Ross, (1995). Fisiologi Tumbuhan, ITB Bandung. 
Thomas L. \& Rajeev, P. (2015). Black pepper - Extensiton phamplet. ICAR- Indian Institute of Spices Research, Kozhikode, India.

Ulfa M., Marlina, \& Mariana. (2017). Respon pertumbuhan stek lada (Piper nigrum L.) Akibat pemberian hormone auksin. Agrotropika Hayati 4(4),332-341.

Zu C., Wu G., Li Z., Yang J., Wang C., Yu H., \& Wu H. (2016). Regulation of black pepper inflorescense quantity by shading at different growth stages. Photochemistry Photobiology, 92(4),579-586. 